Article

\title{
Antimicrobial and Phytotoxic Activity of Origanum heracleoticum and O. majorana Essential Oils Growing in Cilento (Southern Italy)
}

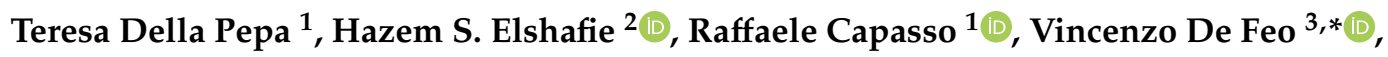 \\ Ippolito Camele ${ }^{2}\left(\mathbb{D}\right.$, Filomena Nazzaro ${ }^{4}$, Maria Rosa Scognamiglio ${ }^{3}(\mathbb{C})$ and Lucia Caputo ${ }^{3}$ \\ 1 Department of Agricultural Sciences, University of Naples Federico II, via Università 100, 80055 Portici, \\ Napoli, Italy \\ 2 School of Agricultural, Forestry, Food and Environmental Sciences, University of Basilicata, Viale \\ dell'Ateneo Lucano 10, 85100 Potenza, Italy \\ 3 Department of Pharmacy, University of Salerno, Via Giovanni Paolo II 132, 84084 Fisciano, Salerno, Italy \\ 4 Institute of Food Science, CNR-ISA, Via Roma 64, 83100 Avellino, Italy \\ * Correspondence: defeo@unisa.it
}

Academic Editor: Daniela Rigano

Received: 27 June 2019; Accepted: 14 July 2019; Published: 16 July 2019

\begin{abstract}
There is a growing interest in a potential use of essential oils (EOs) as a replacement for traditional pesticides and herbicides. The aims of this study were to: (i) Identify the chemical composition of the two EOs derived from Origanum heracleoticum L. and O. majorana L., (ii) evaluate the in vitro antifungal activity of the EOs against some postharvest phytopathogens (Botrytis cinerea, Penicillium expansum, Aspergillus niger and Monilinia fructicola), (iii) evaluate the in vitro antibacterial activity against Bacillus megaterium, Clavibacter michiganensis, Xanthomonas campestris, Pseudomonas fluorescens and P. syringae pv. phaseolicola, (iv) evaluate the effect of both studied EOs on the spore germination percentage and their minimum inhibitory concentration (MIC) against M. fructicola, and (v) study the possible phytotoxicity of the two EOs and their major constituents, carvacrol for O. heracleoticum and terpinen-4-ol for O. majorana, against tha germination and initial radicle growth of radish, lettuce, garden cress and tomato. The two EOs demonstrated promising in vitro antimicrobial and antifungal activities against all tested microorganisms. EOs showed high inhibition of spore germination percentage at the minimal inhibitory concentration of 500 and $2000 \mu \mathrm{g} / \mathrm{mL}$, respectively. Moreover, both germination and radical elongation of selected plant species were sensitive to the oils.
\end{abstract}

Keywords: Origanum heracleoticum; Origanum majorana; antimicrobial activity; phytotoxic activity; spore germination; minimum inhibitory concentration

\section{Introduction}

The control of pathogens and of weeds is a matter of importance in agriculture and synthetic pesticides are commonly used in their treatment, being highly effective in treatments in fields and stored products. However public concern is growing about the possible health and environmental risks related to the increased levels of pesticides and antibiotics in orchards and agriproducts. Considering also the resistance of pests to common agrochemicals, the need for alternative and safe pesticides and antibiotics encourages the exploitation of new sources, namely in the field of natural products [1]. In fact, there is a growing interest in a potential use of essential oils (EOs) as a replacement for traditional antibiotics, pesticides and herbicides. EOs are variable mixtures of volatile compounds produced by aromatic plants as secondary metabolites and are reported for their inhibitory activity against the growth of 
bacteria, yeasts and moulds, showing a variety of targets, particularly the membrane and cytoplasm, and in certain situations, they completely alter the morphology of the cells [2]. For a long time, EOs have been reported for their biological activities on seed germination and plant development [3].

Some essential oils (EOs) have been reported also for their allelopatic potential; in fact, they are capable of inhibiting the growth and/or the germination of competing plants in the surrounding environment [4], and they have also a broad spectrum of activity against plant pathogenic bacteria and fungi [5]. For these proprieties, there is a growing interest in the use of essential oils as an alternative for chemical herbicides, pesticides and antibiotics [6].

Origanum heracleoticum L. and O. majorana L. are two aromatic plants belonging to Labiatae family, native to the Mediterranean area.

O. heracleoticum L. is also known as 'Greek oregano'; its EO, rich in phenols, shows antioxidant, antimicrobial, cytotoxic, antifungal proprieties. Moreover, it is used in aromatherapy as a co-adjuvant in the treatment of bronchitis, rheumatisms, gastroenteritis [7].

O. majorana L., usually known as a culinary additive, is also used in cosmetic industry and as a product with emotional, neurological and health benefits. Moreover, it is known for its antibacterial, antifungal and antiviral activities [8].

This study has been carried out to (i) investigate the chemical characterization of O. heracleoticum and O. majorana, (ii) evaluate the antimicrobial activity of the two EOs against some post-harvest phytopathogenic fungi: Botrytis cinerea, Penicillium expansum, Aspergillus niger and Monilinia fructicola and also some phytopathogenic bacteria (the Gram-positive Bacillus megaterium and Clavibacter michiganensis and the Gram-negative Xanthomonas campestris, Pseudomonas fluorescens, and P. syringae pv. phaseolicola), and (iii) study the possible phytotoxic activity of the two EOs and their main constituents on germination and radical elongation of Raphanus sativus L. (radish), Lactuca sativa L. (lettuce), Lepidium sativum L. (garden cress) and Solanum lycopersicum L. (tomato).

\section{Results and Discussion}

\subsection{GC-MS Analysis}

Hydrodistillation of the aerial parts of O. heracleoticum and O. majorana furnished pale yellow oils in $1.8 \%$ and $0.4 \%$ yield on a dry mass basis, respectively. Tables 1 and 2 show respectively the chemical composition of the two EOs in percent; compounds are listed according to their elution order on a HP-5MS column. The GC profile of two essential oils are present in Figure 1. Altogether, 55 compounds were identified, 35 for O. heracleoticum, accounting for $97.8 \%$ of the total oil, and 20 for O. majorana, accounting for $98.0 \%$ of the total oil.

Oxygenated monoterpenes $(80.1 \%)$ are the main constituents in O. heracleoticum EO, and monoterpene hydrocarbons $(54.0 \%)$ are present in major percent in O. majorana $\mathrm{EO}$.

In the oil from O. heracleoticum carvacrol $(77.8 \%), p$-cimene $(5.3 \%), \gamma$-terpinene $(4.9 \%)$ and (E)-caryophyllene $(1.3 \%)$ are the main components. In the oil from O. majorana, the main compounds are terpinen-4-ol (29.6\%), $\delta$-2-carene $(20.1 \%)$, camphene $(13.4 \%)$ and $\alpha$-pinene $(7.9 \%)$.

Other compounds, in a lesser amount are germacrene A $(0.8 \%), \alpha$-thujene $(0.7 \%)$ and terpinen-4-ol $(0.5 \%)$ for O. heracleoticum, and trans isolimonene (5.4\%), cis-sabinene hydrate $(5.4 \%), \alpha$-terpinene $(4.2 \%)$ and $\alpha$-terpineol (2.8\%) for O. majorana. 
Table 1. Chemical composition of O. heracleoticum essential oil.

\begin{tabular}{|c|c|c|c|c|c|}
\hline No. & Compounds & $\%$ & $\mathrm{KI}^{\mathrm{a}}$ & $\mathrm{KI}^{\mathrm{b}}$ & Identification $^{c}$ \\
\hline 1 & $\alpha$-Thujene & 0.7 & 856 & 930 & $1,2,3$ \\
\hline 2 & $\alpha$-Pinene & 0.4 & 860 & 939 & $1,2,3$ \\
\hline 3 & Camphene & 0.1 & 871 & 954 & $1,2,3$ \\
\hline 4 & Sabinene & 0.4 & 896 & 975 & $1,2,3$ \\
\hline 5 & $\beta$-Pinene & 1.0 & 914 & 979 & $1,2,3$ \\
\hline 6 & $\alpha$-Phellandrene & 0.2 & 922 & 1002 & $1,2,3$ \\
\hline 7 & $\delta$-3-Carene & 0.1 & 927 & 1011 & 1,2 \\
\hline 8 & $\alpha$-Terpinene & 1.1 & 934 & 1017 & $1,2,3$ \\
\hline 9 & $\rho$-Cimene & 5.3 & 944 & 1024 & 1,2 \\
\hline 10 & Limonene & 0.3 & 946 & 1029 & $1,2,3$ \\
\hline 11 & 1,8 Cineol & 0.1 & 947 & 1031 & $1,2,3$ \\
\hline 12 & (E)- $\beta$-Ocimene & 0.1 & 966 & 1050 & $1,2,3$ \\
\hline 13 & $\gamma$-Terpinene & 4.9 & 977 & 1059 & $1,2,3$ \\
\hline 14 & cis-Sabinene hydrate & 0.3 & 983 & 1070 & 1,2 \\
\hline 15 & Terpinolene & 0.1 & 1000 & 1088 & 1,2 \\
\hline 16 & Linalool & 0.4 & 1017 & 1096 & $1,2,3$ \\
\hline 17 & trans-Sabinene hydrate & $\mathrm{t}$ & 1033 & 1098 & 1,2 \\
\hline 18 & allo-Ocimene & 0.1 & 1040 & 1132 & 1,2 \\
\hline 19 & Borneol & 0.4 & 1073 & 1169 & $1,2,3$ \\
\hline 20 & Terpinen-4-ol & 0.5 & 1083 & 1177 & $1,2,3$ \\
\hline 21 & $\alpha$-Terpineol & 0.1 & 1097 & 1188 & $1,2,3$ \\
\hline 22 & cis-Dihydrocarvone & 0.1 & 1110 & 1192 & 1,2 \\
\hline 23 & trans-Dihydrocarvone & $\mathrm{t}$ & 1106 & 1200 & 1,2 \\
\hline 24 & Thymol methyl ether & 0.3 & 1146 & 1235 & 1,2 \\
\hline 25 & Thymoquinone & $\mathrm{t}$ & 1151 & 1252 & 1,2 \\
\hline 26 & Thymol & 0.1 & 1204 & 1290 & $1,2,3$ \\
\hline 27 & Carvacrol & 77.8 & 1218 & 1299 & $1,2,3$ \\
\hline 28 & Eugenol & 0.2 & 1261 & 1359 & $1,2,3$ \\
\hline 29 & (E)-Caryophyllene & 1.3 & 1303 & 1419 & 1,2 \\
\hline 30 & Aromadendrene & $\mathrm{t}$ & 1320 & 1441 & $1,2,3$ \\
\hline 31 & $\alpha$-Humulene & 0.2 & 1335 & 1454 & $1,2,3$ \\
\hline 32 & Aceto-vanillone & 0.1 & 1346 & 1482 & 1,2 \\
\hline 33 & Germacrene A & 0.8 & 1389 & 1509 & 1,2 \\
\hline 34 & Caryophyllene oxide & 0.2 & 1452 & 1583 & $1,2,3$ \\
\hline \multirow[t]{6}{*}{35} & $\alpha$ Bisabolol & $\mathrm{t}$ & 1150 & 1685 & $1,2,3$ \\
\hline & Total & 97.8 & & & \\
\hline & Monoterpene hydrocarbons & 15.1 & & & \\
\hline & Oxygenated monoterpenes & 80.1 & & & \\
\hline & Sesquiterpene hydrocarbons & 2.3 & & & \\
\hline & Oxygenated sesquiterpenes & 0.2 & & & \\
\hline
\end{tabular}

${ }^{a}$ Linear retention index on a HP-5MS column; ${ }^{b}$ Linear retention index on a HP Innowax column; ${ }^{\mathrm{c}}$ Identification method: 1 = linear retention index; 2 = identification based on the comparison of mass spectra; $3=$ Co-injection with standard compounds. 
Table 2. Chemical composition of O. majorana essential oil.

\begin{tabular}{|c|c|c|c|c|c|}
\hline No. & Compounds & $\%$ & $\mathrm{~K}^{\mathrm{a}}$ & $\mathbf{K}^{\mathbf{b}}$ & Identification $^{c}$ \\
\hline 1 & $\alpha$-Thujene & 0.4 & 856 & 930 & $1,2,3$ \\
\hline 2 & $\alpha$-Pinene & 7.9 & 895 & 939 & $1,2,3$ \\
\hline 3 & $\alpha$-Fenchene & 2.2 & 914 & 951 & 1,2 \\
\hline 4 & Camphene & 13.4 & 934 & 954 & $1,2,3$ \\
\hline 5 & Verbetene & 0.4 & 942 & 967 & 1,2 \\
\hline 6 & trans-Isolimonene & 5.4 & 945 & 984 & 1,2 \\
\hline 7 & $\delta$-2-Carene & 20.1 & 974 & 1002 & 1,2 \\
\hline 8 & $\alpha$-Terpinene & 4.2 & 1000 & 1017 & $1,2,3$ \\
\hline 9 & cis- Sabinene hydrate & 5.4 & 1009 & 1070 & 1,2 \\
\hline 10 & Linalool & 1.0 & 1017 & 1096 & $1,2,3$ \\
\hline 11 & cis-p-Menth-2-en-1-ol & 0.8 & 1033 & 1121 & 1,2 \\
\hline 12 & allo-Ocimene & $t$ & 1040 & 1132 & $1,2,3$ \\
\hline 13 & trans-p-Menth-2-en-1-ol & 0.4 & 1051 & 1177 & 1,2 \\
\hline 14 & Terpinen-4-ol & 29.6 & 1083 & 1177 & 1,2 \\
\hline 15 & $\alpha$-Terpineol & 2.8 & 1087 & 1188 & 1,2 \\
\hline 16 & Thymol & 0.3 & 1204 & 1290 & $1,2,3$ \\
\hline 17 & Carvacrol & 0.6 & 1218 & 1299 & $1,2,3$ \\
\hline 18 & $\delta$-Elemene & 0.5 & 1227 & 1338 & 1,2 \\
\hline 19 & (E)-Caryophyllene & 2.2 & 1003 & 1419 & $1,2,3$ \\
\hline \multirow[t]{5}{*}{20} & cis-Muurola-3,5-diene & 0.2 & 1353 & 1450 & 1,2 \\
\hline & Total & 98.0 & & & \\
\hline & Monoterpene hydrocarbons & 54.0 & & & \\
\hline & Oxygenated monoterpenes & 40.9 & & & \\
\hline & Sesquiterpene hydrocarbons & 2.9 & & & \\
\hline
\end{tabular}

a Linear retention index on a HP-5MS column; ${ }^{\mathrm{b}}$ Linear retention index on a HP Innowax column; ${ }^{\mathrm{c}}$ Identification method: 1 = linear retention index; 2 = identification based on the comparison of mass spectra; $3=$ Co-injection with standard compounds.

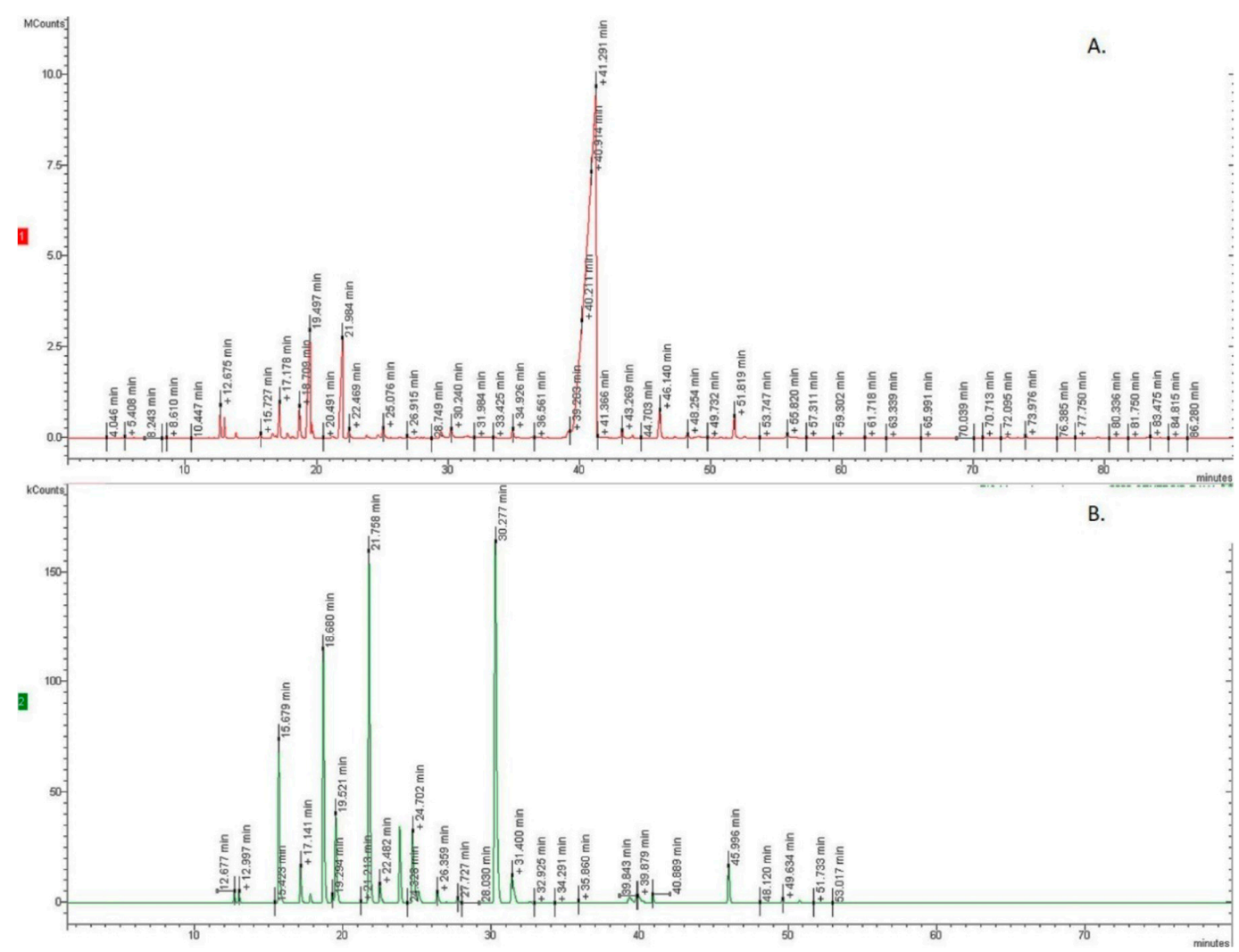

Figure 1. The Gas Chromatography (GC) profile of O. heracleoticum (A) and O. majorana essential oils (B). 
Our data about the chemical composition of O. heracleoticum EO agrees with data previously reported, which identified carvacrol as the main component of this oil. Conversely, in our study thymol, generally considered as one of principal constituents (ranging from $7.47-42.8 \%$ of total oil) was present in a very low quantity $(0.3 \%)$ [9-11].

The chemical composition of our O. majorana $\mathrm{EO}$ is similar to data reported in literature. Terpinen-4-ol was confirmed as the most abundant component of $O$. majorana $\mathrm{EO}$, as also demonstrated by Abbassy and co-workers, which reported a percentage of such compound ranging from $29.9 \%$ to $38.8 \%$ [12]. Similarly, $\gamma$-terpinene was reported as one of the major components $[12,13]$; in our study its isomer, $\alpha$-terpinene, was present. Such a scenario did not coincide with data reported by Brosche et al. [13], which indicated cis-sabinene hydrate as one of main compounds of O. majorana EO present in equal percent to terpinen-4-ol; on the contrary, in our sample its concentration amounted to just $5.4 \%$. Furthermore, in our analysis, we did not find 1,8-cineole, which conversely is indicated as the main component of O. majorana EO from Salerno (Italy) [3].

\subsection{Antifungal In Vitro Test}

O. heracleoticum EO was able to inhibit significantly the growth of all tested fungi and at all concentrations tested, instead O. majorana EO inhibited only three fungi (M. fructicola, P. expansum and A. niger) (Figure 2). Our results confirm the data of previous studies in which O. heracleoticum essential oil inhibited mycelial growth of Penicillium expansum isolated from organic cultivation of tomato [14]; and of Monilinia species [6].

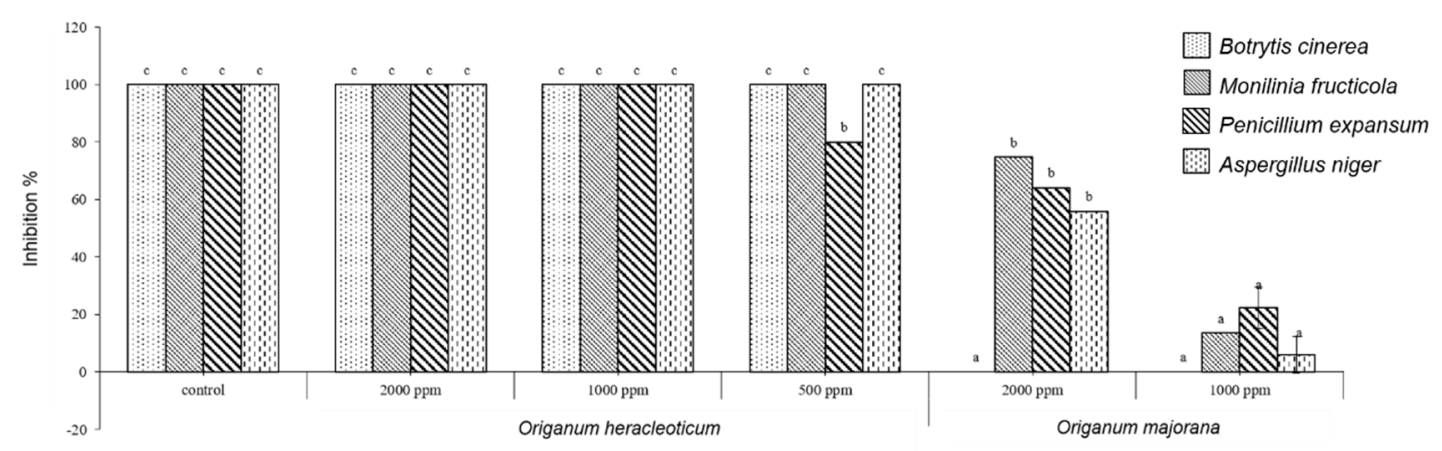

Figure 2. Antifungal activity of O. heracleoticum and O. majorana EOs. Bars with different letters for each tested fungi indicate mean values significantly different at $p<0.05$ according to Tukey B test between different tested concentrations. Data are expressed as mean \pm SDs.

Different studies reported that $O$. majorana essential oil showed antifungal activity against $B$. cinerea and P. expansum $[1,15]$, whereas in our study this essential oil was not active against $B$. cinerea. No studies reported data on $O$. heracleoticum essential oil against $B$. cinerea and $A$. niger and on O. majorana essential oil against $A$. niger.

However, different studies reported an antifungal activity of plants belonging to Origanum genus. For example, O. dictamnus essential oil is active against the growth of $B$. cinerea [16]; O. vulgare against P. expansum $[17,18]$ and O. minutiflorum against $A$. niger [19].

The efficacy of these EOs probably depends on their bioactive lipophilic constituents that play an essential role in degradation of fungal phytopathogens cell membrane [20]. Moreover, carvacrol, the main constituent of $O$. heracleoticum essential oil can act on the loss of proton gradient disturbing the cellular membrane [21].

\subsection{Antibacterial In Vitro Test}

The EOs showed a good antibacterial efficacy against the tested bacteria compared to the control. In fact, $O$. heracleoticum and O. majorana EOs were able to inhibit the growth of all Gram-negative bacteria tested at $12 \mathrm{mg} / \mathrm{mL}$, whereas with concentration of $6 \mathrm{mg} / \mathrm{mL}$ the two EOs inhibited only 
the growth of Pseudomonas syringae pv. phaseolicola (Figure 3). Moreover, the two EOs showed more bactericidal effects against Gram-positive bacteria than against Gram-negative, inhibiting the growth of Clavibacter michiganensis at all tested concentrations in a dose-dependent manner (Figure 4) and O. heracleoticum was also active against B. megaterium but only at concentration of $12 \mathrm{mg} / \mathrm{mL}$.

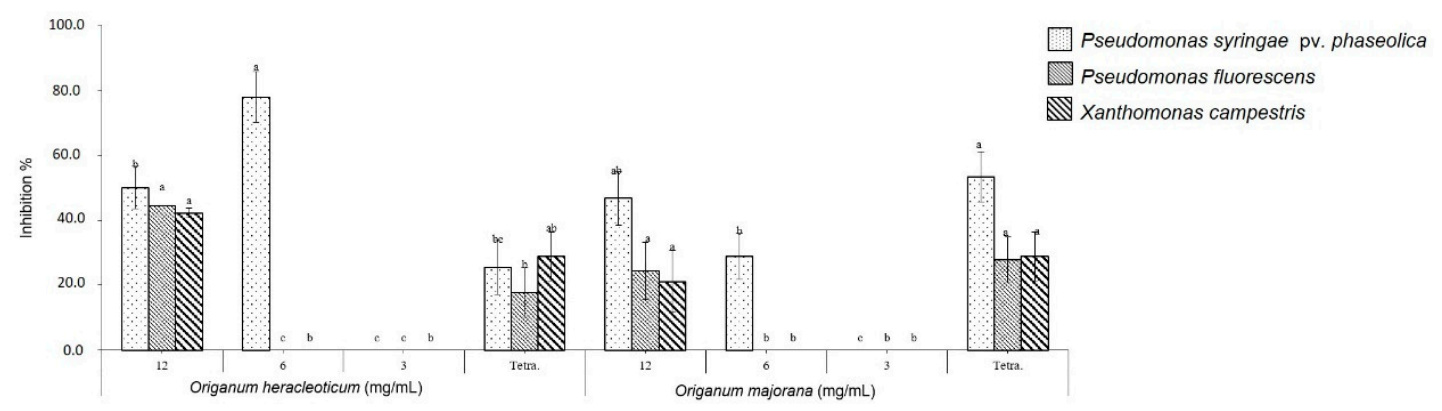

Figure 3. Antibacterial activity of $O$. heracleoticum and O. majorana EOs against G-ve bacteria. Bars with different letters for each tested bacteria indicate mean values significantly different at $p<0.05$ according to the Tukey B test between different tested concentrations. Data are expressed as mean \pm SDs.

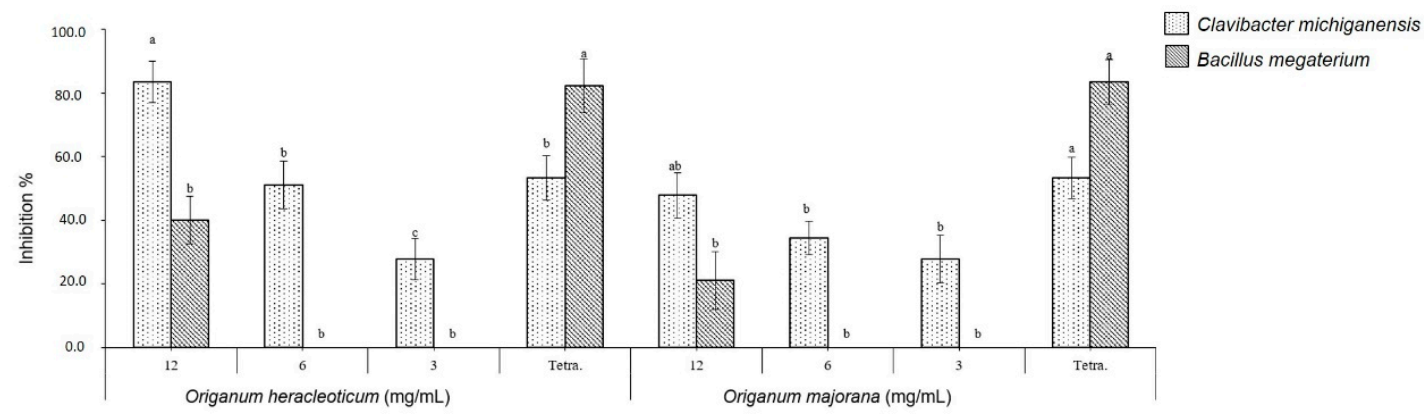

Figure 4. Antibacterial activity of $O$. heracleoticum and O. majorana EOs against Gram-positive bacteria. Bars with different letters for each tested bacteria indicate mean values significantly different at $p<0.05$ according to the Tukey B test between different tested concentrations. Data are expressed as mean \pm SDs.

The potential efficacy of tested EOs against bacterial cells can depend on the ability of EOs to increase the cell membrane permeability and enhance the loss of ions, leakage of macromolecules and lysis [2].

Our results agree with previous studies on antibacterial activity of $O$. heracleoticum and O. majorana essential oil. In fact, they first showed an antibacterial activity against Bacillus megaterium [22], whereas $P$. aeruginosa appear to be the most resistant to the action of this essential oil [23]. Instead, O. majorana EO showed antibacterial activity against several plant pathogenic bacteria, such as B. megaterium, Clavibacter michiganensis, Xanthomonas campestris, and P. syringae pv. Phaseolicola [15,24,25]. However, no studies reported antibacterial activity of $O$. heracleoticum $\mathrm{EO}$ against $C$. michiganensis, $X$. campestris and $P$. syringae pv. phaseolicola and of O. majorana EO against $P$. fluorescens.

\subsection{Fungal Spore Germination Assay}

As presented in Table 3, O. heracleoticum and O. majorana EOs significantly inhibited the fungal spore germination of $M$. fructicola $(p<0.05)$ in a dose-dependent manner. In particular, the spore germination was reduced gradually from $79 \%$ to $94 \%$ and from $76 \%$ to $93 \%$ by increasing the concentration of O. heracleoticum and O. majorana EOs from 15 to $45 \mu \mathrm{g} / \mu \mathrm{l}$, respectively. No previous studies reported data of spore germination assay for the two EOs against M. fructicola. 
Table 3. Evaluation the effect of $O$. heracleoticum and O. majorana EOs on the spore germination of Monilinia fructicola.

\begin{tabular}{ccccc}
\hline EOs & & ${ }^{*}$ Spore/mL & ${ }^{* *}$ Spore Germination \% & ${ }^{* * *}$ Inhibition Rate \% \\
\hline & Control & $80.0 \times 10^{4}$ & 100.0 & 0.0 \\
\hline \multirow{3}{*}{ O. heracleoticum EO } & $15 \mu \mathrm{g} / \mu \mathrm{L}$ & $16.7 \times 10^{4}$ & $20.9^{\mathrm{a}}$ & $79.1^{\mathrm{ab}}$ \\
& $22 \mu \mathrm{g} / \mu \mathrm{L}$ & $92.5 \times 10^{4}$ & $11.6^{\mathrm{b}}$ & $88.4^{\mathrm{a}}$ \\
& $45 \mu \mathrm{g} / \mu \mathrm{L}$ & $45.0 \times 10^{4}$ & $5.6^{\mathrm{b}}$ & $94.4^{\mathrm{a}}$ \\
\hline \multirow{2}{*}{ O. majorana $\mathrm{EO}$} & $15 \mu \mathrm{g} / \mu \mathrm{L}$ & $16.8 \times 10^{4}$ & $23.5^{\mathrm{a}}$ & $76.5^{\mathrm{ab}}$ \\
& $22 \mu \mathrm{g} / \mu \mathrm{L}$ & $10.2 \times 10^{4}$ & $12.8^{\mathrm{ab}}$ & $87.2^{\mathrm{a}}$ \\
& $45 \mu \mathrm{g} / \mu \mathrm{L}$ & $5.5 \times 10^{4}$ & $6.9^{\mathrm{ab}}$ & $93.1^{\mathrm{a}}$ \\
\hline
\end{tabular}

$\left(^{*}\right)$ : Spores $/ \mathrm{mL}=$ average number of spores $\times 10^{4} ;\left(^{* *}\right)$ : Spore germination $\%=($ total number of spore in treated media / total number of spores in control $\times 100 ;(* * *)$ : Inhibition rate $\%=$ percentage of spore germination in control-percentage of spore germination in treated media, and $(a, b, a b)$ different letters indicates the significant differences at $p \leq 0.05$.

\subsection{Determination of Minimum Inhibitory Concentration (MIC) (96-Well Microplate Method)}

Results of the MIC assay of $O$. heracleoticum EO against $M$. fructicola were variable for the five different tested concentrations ranging between 100 and $500 \mu \mathrm{g} / \mathrm{mL}$. The MIC value was recorded as the minimum absorbance reading close to the PDB value as a negative control. In particular, O. heracleoticum EO strongly inhibited the tested fungi and showed the lowest absorbance $(0.028 \mathrm{~nm})$ regarding the MIC value of the highest tested concentration $(500 \mu \mathrm{g} / \mathrm{mL})$ after $72 \mathrm{~h}$ of incubation at $24 \pm 2{ }^{\circ} \mathrm{C}$ (Figure 5). It was observed also that there is a dramatic decrease of fungal mycelium growth by increasing the concentration of O. heracleoticum EO more than $300 \mu \mathrm{g} / \mathrm{mL}$, especially after 48 and $72 \mathrm{~h}$ of incubation (Figure 5).

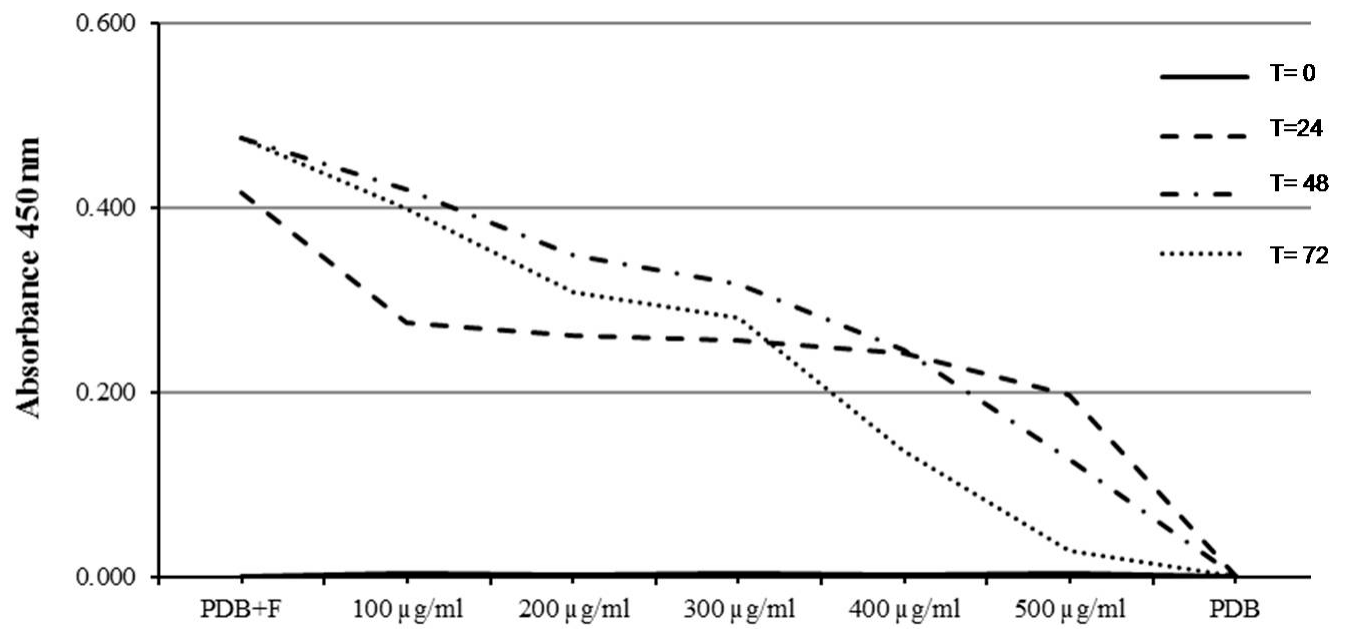

Figure 5. Minimum inhibitory concentration (MIC) of O. heracleoticum EO against Monilinia fructicola.

On the other hand, the MIC of O. majorana EO against $M$. fructicola was less variable, especially for the first three days of incubation, whereas a high variability of fungal growth decrease was registered after $72 \mathrm{~h}$ for 2000 and $2400 \mu \mathrm{g} / \mathrm{mL}$. The MIC value of O. majorana EO was 0.413 and $0.342 \mathrm{~nm}$ using 2000 and $2400 \mu \mathrm{g} / \mathrm{mL}$, respectively (Figure 6). In addition, a decrease was observed with a concentration higher than $2000 \mu \mathrm{g} / \mathrm{mL}$ and after two days of incubation (Figure 6). There are no studies in literature that reported data of MIC assay for M. fructicola after treatment with O. heracleoticum and O. majorana essential oils. 


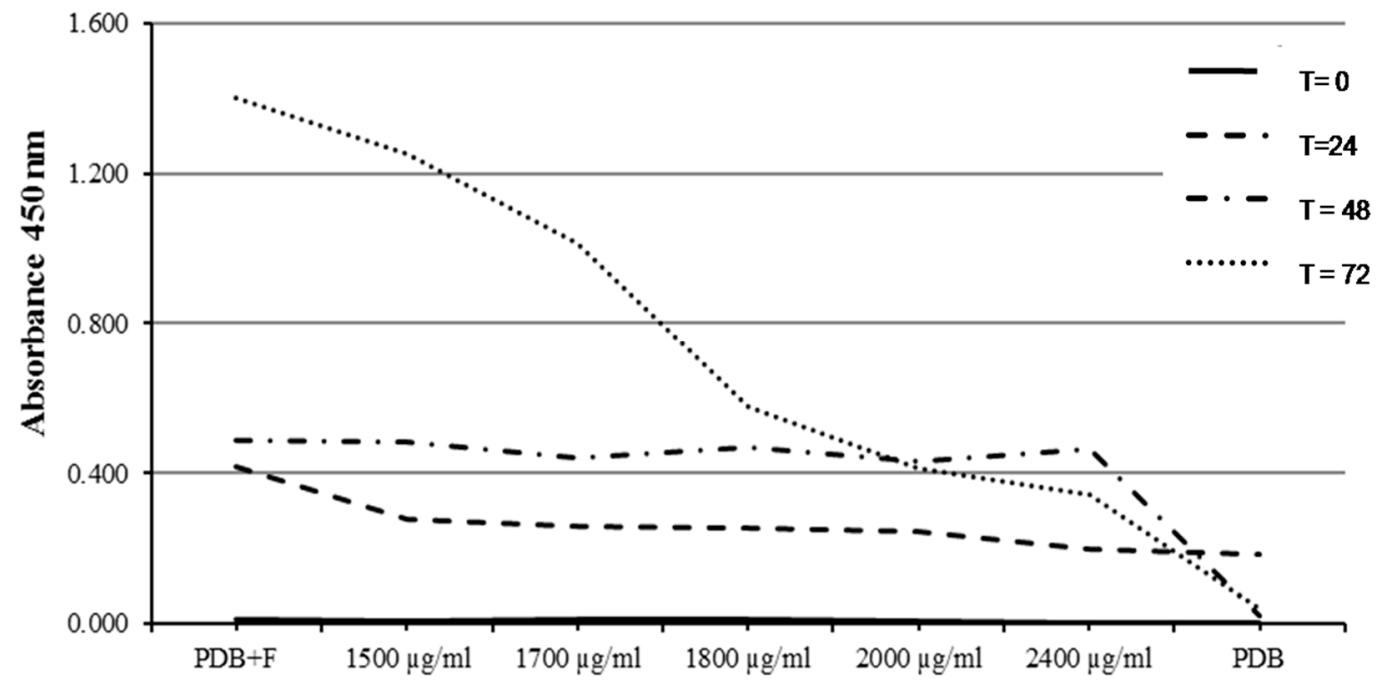

Figure 6. MIC of O. majorana EO against Monilinia fructicola.

\subsection{Phytotoxic Activity}

The two EOs and their main constituents, carvacrol and terpinen-4-ol, were evaluated for their activity against germination and radical elongation of radish, lettuce, garden cress and tomato.

$O$. heracleoticum EO seemed to be effective against radical elongation and germination of L. sativa, L. sativum and S. lycopersicum (Figures 7 and 8). In particular, the treatment of seeds with concentrations of $100 \mathrm{and} 10 \mu \mathrm{g} / \mathrm{mL}$ of the oil inhibited the radical elongation of L. sativa; all doses tested affected significantly the radical elongation of $L$. sativum and only the concentration of $10 \mu \mathrm{g} / \mathrm{mL}$ inhibited the grown of S. lycopersicum (Figure 7). However, O. heracleoticum EO was active against its germination (Figure 8).
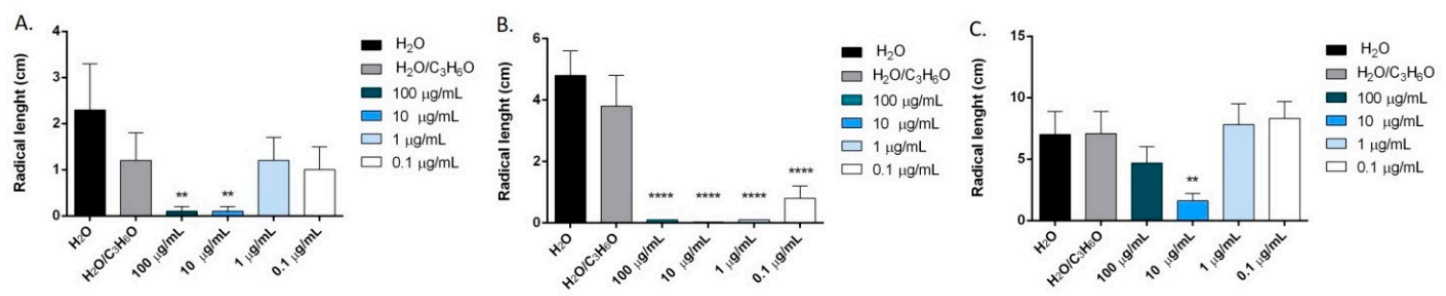

Figure 7. Phytotoxic activity of $O$. heracleoticum essential oil against radical elongation of L. sativa (A), L. sativum (B), S. lycopersicum (C). Results are expressed as the mean of three experiments standard deviation. ${ }^{* *} p<0.01,{ }^{* * * *} p<0.0001$ compared to control (ANOVA followed by Dunnett's multiple comparison test).

A.

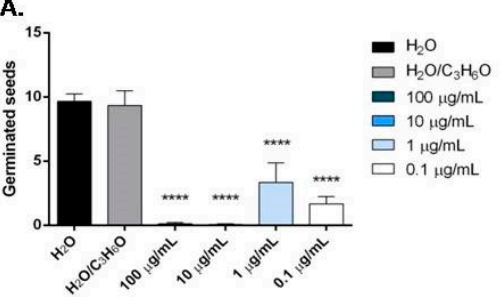

B.

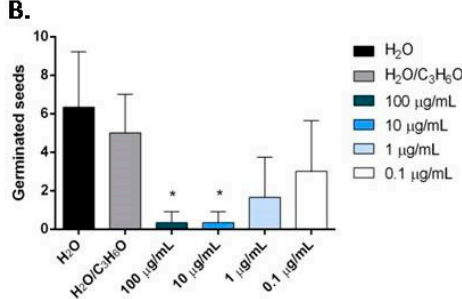

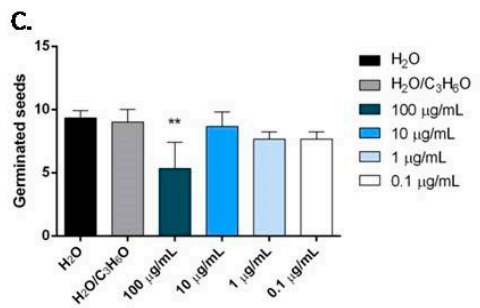

Figure 8. Phytotoxic activity of $O$. heracleoticum essential oil against germination of L. sativa (A), L. sativum (B), S. lycopersicum (C) seeds. Results are expressed as the mean of three experiments standard deviation. ${ }^{*} p<0.05,{ }^{* *} p<0.01,{ }^{* * *} p<0.0001$ compared to control (analysis of variance (ANOVA) followed by Dunnett's multiple comparison test). 
Our results agree with Elshafie et al. [22]. In fact, they demonstrated that the EO obtained from O. heracleoticum growing in Basilicata (Italy) inhibited germination and radical elongation of L. sativum and R. sativus. Moreover, our data confirmed the strong phytotoxic effect of this EO also tested on growth of Arabidopsis rosettes [26].

Carvacrol was more active than $O$. heracleoticum EO against radical elongation of all tested seeds and germination of L. sativa and S. lycopersicum (Figures 9 and 10). In fact, this compound inhibited significantly, at all doses tested, the radical elongation of L. sativa and of L. sativum and at concentration of $100 \mu \mathrm{g} / \mathrm{mL}$ and of $10 \mu \mathrm{g} / \mathrm{mL}$ the radicle elongation of $R$. sativum and S. lycopersicum seeds (Figure 9). Moreover, carvacrol inhibited the germination of L. sativa, and S. lycopersicum, at concentrations of 100 , $10,1 \mu \mathrm{g} / \mathrm{mL}$ and of 100 and $10 \mu \mathrm{g} / \mathrm{mL}$, respectively (Figure 10).
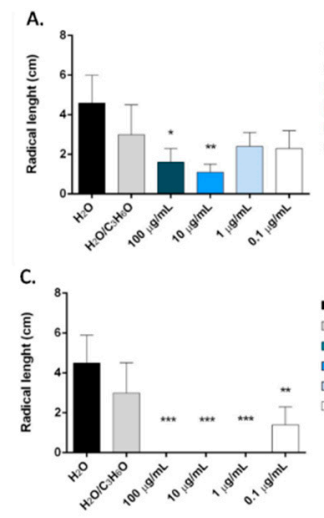

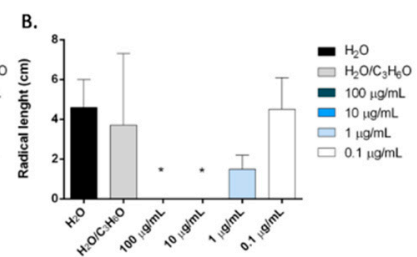

D.
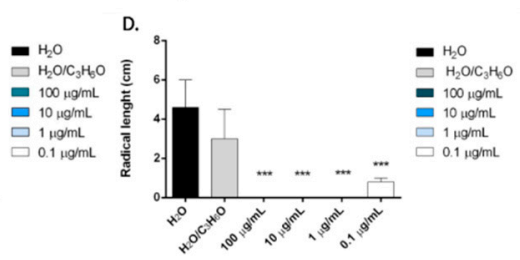

Figure 9. Phytotoxic activity of carvacrol against radical elongation of R. sativum (A), S. lycopersicum (B), L. sativa (C), L. sativum (D). Results are expressed as the mean of three experiments standard deviation. ${ }^{*} p<0.05,{ }^{* *} p<0.01,{ }^{* * *} p<0.001$ compared to control (ANOVA followed by Dunnett's multiple comparison test).
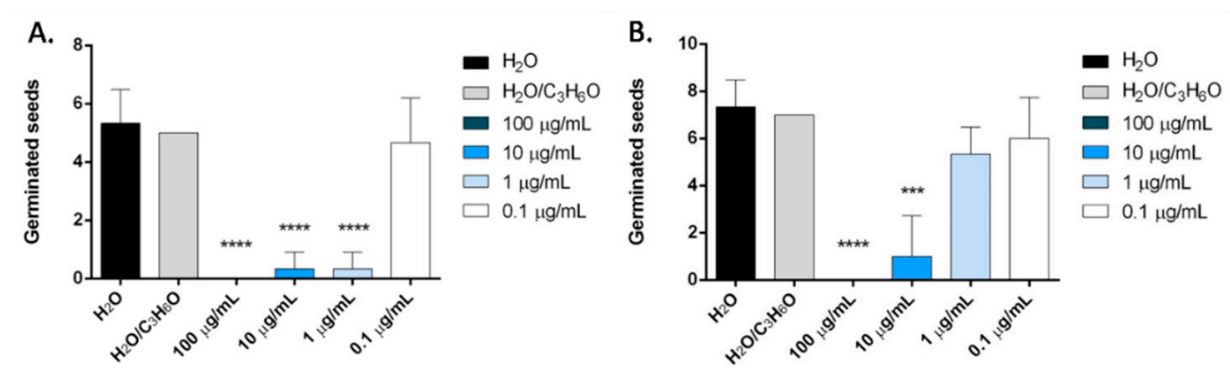

Figure 10. Phytotoxic activity of carvacrol against germination of L. sativa (A) and S. lycopersicum (B). Results are expressed as the mean of three experiments standard deviation. ${ }^{* * *} p<0.001,{ }^{* * * *} p<0.0001$ compared to control (ANOVA followed by Dunnett's multiple comparison test).

Our data are in agreement with previous studies on the herbicidal effect of carvacrol. In fact, this compound inhibited the germination and seedling growth of Amaranthus retroflexus, Chenopodium album and Rumex crispusa, Lolium rigidum, Lactuca sativa and Sorghum bicolour [27-29], and can cause chromosomal alterations in the meristematic cells of L. sativa [30].

O. majorana EO inhibited the radical length of Lepidium sativum at concentrations of 100 and $10 \mu \mathrm{g} / \mathrm{mL}$ and germination of Lactuca sativa at all concentration tested (Figure 11). 
A.

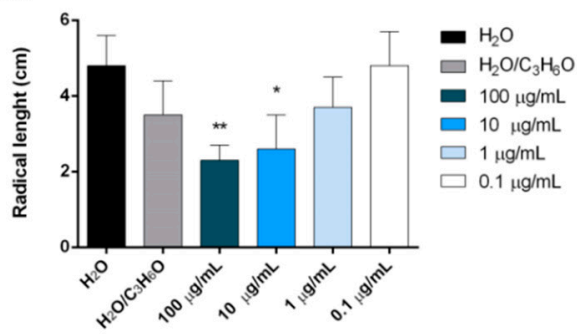

B.

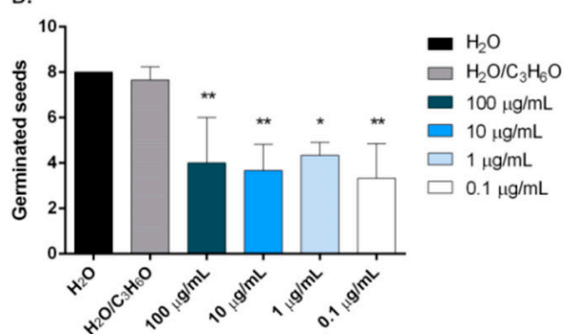

Figure 11. Phytotoxic activity of O. majorana essential oil against radical elongation of L. sativum (A) and against germination of L. sativa (B) seeds. Results are expressed as the mean of three experiments standard deviation. ${ }^{*} p<0.05,{ }^{* *} p<0.01$ compared to control (ANOVA followed by Dunnett's multiple comparison test).

There is only one previous study on phytotoxic activity of O. majorana EO [3]. In this research the EO was active on both radical elongation and germination of L. sativa, L. sativum and R. sativum, but this could be due to different chemical compositions of this EO, which was rich mainly of 1,8 cineole.

In our study, we also evaluated for the first time the potential phytotoxic activity of terpinen-4-ol, the main constituent of O. majorana EO. Results showed that this compound inhibited the radical elongation and germination of all tested seeds (Figures 12 and 13).

In particular, on L. sativum, S. lycopersicum and R. sativum seeds, all concentrations tested significantly reduced the radical length, instead, on $L$. sativa seeds, the effect was evident at concentrations of 100 and $10 \mu \mathrm{g} / \mathrm{mL}$ (Figure 12).

The inhibition of germination was more evident on Solanum lycopersicum seeds, where an inhibition of germination was observed for all concentrations used $(100-0.1 \mu \mathrm{g} / \mathrm{mL})$. The effectiveness was less evident on R. sativum, L. sativa and L. sativum seeds, and only the two major concentrations used (100 and $10 \mu \mathrm{g} / \mathrm{mL}$ ) demonstrated dose-dependent inhibitory activity (Figure 13).

A.
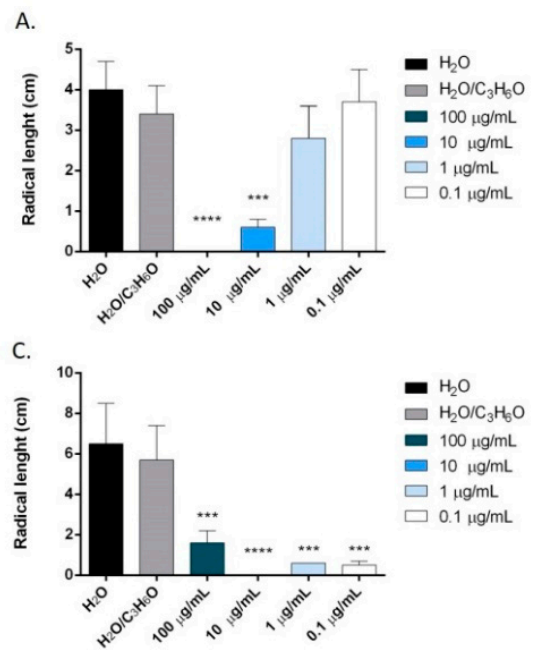

B.

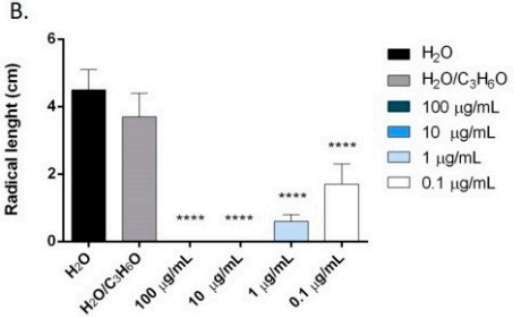

D.

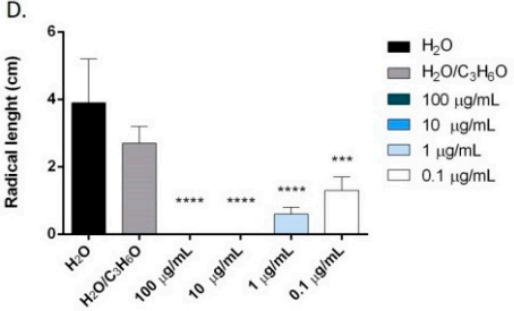

Figure 12. Phytotoxic activity of terpinen-4-ol against radical elongation of L. sativa (A), L. sativum (B), S. lycopersicum (C), R. sativum (D). Results are expressed as the mean of three experiments standard deviation. ${ }^{* * *} p<0.001,{ }^{* * * *} p<0.0001$ compared to control (ANOVA followed by Dunnett's multiple comparison test). 
A.

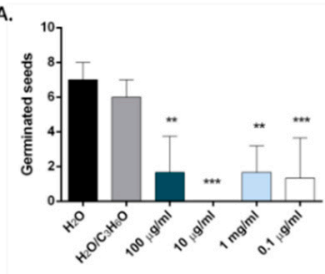

c.

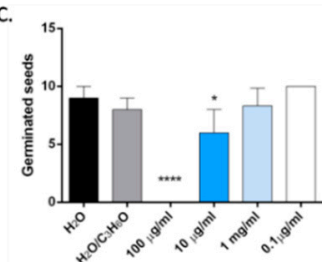

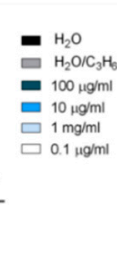
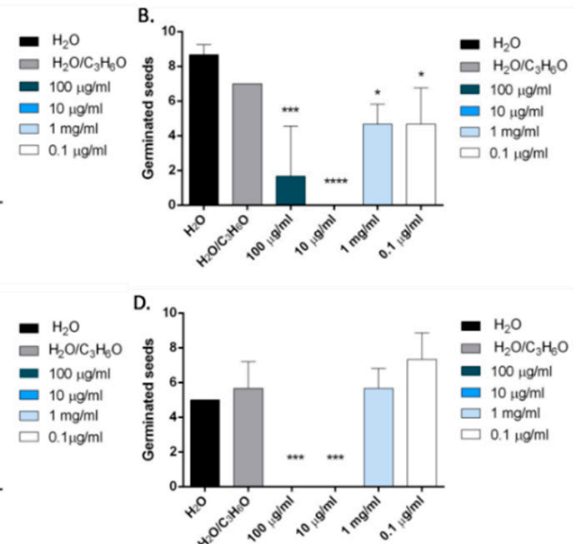

Figure 13. Phytotoxic activity of terpinen-4-ol against germination of S. lycopersicum (A), R. sativum (B), L. sativa (C), L. sativum L. (D). Results are expressed as the mean of three experiments standard deviation. ${ }^{*} p<0.05,{ }^{* *} p<0.01,{ }^{* * *} p<0.001,{ }^{* * * *} p<0.0001$ compared to control (ANOVA followed by Dunnett's multiple comparison test).

\section{Materials and Methods}

\subsection{Plant Materials}

Representative homogeneous samples of O. heracleoticum and O. majorana were collected in September 2018, in Montecorice, Salerno province (Southern Italy). The plants were identified by Prof. V. De Feo, based on Flora d'Italia [31] and a voucher specimen of each plant has been deposited in the herbarium of the Medical Botany Chair of University of Salerno.

\subsection{Isolation of the Volatile Oil}

One kilogram of dried aerial parts of O. heracleoticum and of O. majorana were ground in a Waring blender and then subjected to hydrodistillation for $3 \mathrm{~h}$ according to the standard procedure described in the European Pharmacopoeia [32]. The oils were solubilized in $n$-hexane, filtered over anhydrous sodium sulphate and stored under $\mathrm{N}_{2}$ at $+4{ }^{\circ} \mathrm{C}$ in the dark until tested and analyzed.

\subsection{Gas Chromatography-Flame Ionization Detector (GC-FID) Analysis}

Analytical gas chromatography was carried out on a Perkin-Elmer Sigma-115 gas chromatograph equipped with a FID and a data handling processor. The separation was achieved using a HP-5 MS fused-silica capillary column $(30 \mathrm{~m} \times 0.25 \mathrm{~mm}$ i.d., $0.25 \mu \mathrm{m}$ film thickness). Column temperature: $40{ }^{\circ} \mathrm{C}$, with $5 \mathrm{~min}$ initial hold, and then to $270{ }^{\circ} \mathrm{C}$ at $2{ }^{\circ} \mathrm{C} / \mathrm{min}, 270{ }^{\circ} \mathrm{C}$ (20 min); injection mode splitless (1 $\mu \mathrm{L}$ of a 1:1000 $n$-hexane solution). Injector and detector temperatures were $250{ }^{\circ} \mathrm{C}$ and $290{ }^{\circ} \mathrm{C}$, respectively. Analysis was also run by using a fused silica HP Innowax polyethylenglycol capillary column (50 $\mathrm{m} \times 0.20 \mathrm{~mm}$ i.d., $0.25 \mu \mathrm{m}$ film thickness) (Santa Clara, CA, USA). In both cases, helium was used as the carrier gas $(1.0 \mathrm{~mL} / \mathrm{min})$.

\subsection{GC/Mass Spectroscopy (MS) Analysis and Identification of Constituents}

Analyses were performed on an Agilent 6850 Ser. II apparatus (Santa Clara, CA, USA), fitted with a fused silica DB-5 capillary column (30 $\mathrm{m} \times 0.25 \mathrm{~mm}$ i.d., $0.33 \mu \mathrm{m}$ film thickness) (Santa Clara, CA, USA), coupled to an Agilent Mass Selective Detector MSD 5973; ionization energy voltage $70 \mathrm{eV}$; electron multiplier voltage energy $2000 \mathrm{~V}$.

Mass spectra were scanned in the range 40-500 amu, scan time 5 scans/s. Gas chromatographic conditions were as reported above, and the transfer line temperature was $295{ }^{\circ} \mathrm{C}$.

Most constituents were identified by gas chromatography by comparison of their Kovats retention indices (Ri) (determined relative to the tR of $n$-alkanes $\left(C_{10}-C_{35}\right)$ ), with either those of the literature [33-36] 
and mass spectra on both columns with those of authentic compounds available in our laboratories by means of the National Institute of Standards and Technology (NIST) and Wiley 275 libraries [37]. The relative concentrations of the single components were obtained by peak area normalization.

\subsection{Antifungal Activity}

\subsubsection{Fungal Isolates}

The tested fungi Botrytis cinerea, Penicillium expansum, Aspergillus niger and Monilinia fructicola were maintained as pure cultures at $4{ }^{\circ} \mathrm{C}$ in the mycotheca of the School of Agricultural, Forestry, Food and Environmental Sciences (SAFE), Basilicata University, Potenza, (Italy) and activated on potato dextrose agar (PDA) at $24 \pm 2{ }^{\circ} \mathrm{C}$. Identification of the isolates was carried out by morphological and molecular methods based on polymerase chain reaction (PCR). The total nucleic acids were extracted from pure culture with a commercial kit (Dneasy Plant mini kit, Qiagen, Hilden, Germany) according to the manufacturer's instructions. The DNA was amplified using the universal primer pair ITS4/ITS5 [38]. The amplicon obtained were directly sequenced and the resulting sequences were compared with those available in GenBank using Basic Local Alignment Search Tool software (BLAST-USA) [39]. Gene sequencing of the internal transcribed spacer (ITS) region confirmed the identification done by traditional methods.

\subsubsection{In Vitro Fungicidal Activity}

The antifungal activity of $O$. heracleoticum and O. majorana were assessed at 2000, 1000 and $500 \mathrm{ppm}$ incorporating directly the EO in potato dextrose agar (PDA) with $0.2 \%$ Tween 20 following the method reported by Elshafie et al. [40]. Fungal discs of $0.5 \mathrm{~cm}$ from fresh cultures were inoculated in the center of Petri dishes containing $14 \mathrm{~mL}$ of PDA. All tested Petri dishes were incubated at $24 \pm 2{ }^{\circ} \mathrm{C}$ for $96 \mathrm{~h}$ and later the diameter of fungal mycelium growth was measured in $\mathrm{mm}$. PDA plates incorporated only with Tween $20(0.2 \%)$ were inoculated with the same tested fungi and used as negative control. The experiment was carried out in triplicate and the fungitoxic effect was expressed as a percentage of growth inhibition (PGI) according to the formula of Zygadlo et al. [41], compared to azoxystrobin $\left(80 \mu \mathrm{L} .100 \mathrm{~mL}^{-1}\right)$ as the positive control:

$$
\text { PGI }(\%)=100 \times(G C-G T) / G C \text {, }
$$

where GC = the average diameter of fungus colony grown on PDA (control), and GT = the average diameter of fungus colony grown on PDA containing each EO.

\subsection{Antibacterial Activity Assay}

\subsubsection{Bacterial Isolates}

The test was performed using different Gram-positive (Bacillus megaterium and Clavibacter michiganensis) and Gram-negative (Xanthomonas campestris, Pseudomonas fluorescens, and P. syringae pv. phaseolicola) bacteria. The tested strains were cultured on King B (KB) media and incubated at $30 \pm 2{ }^{\circ} \mathrm{C}$ for $72 \mathrm{~h}$. All tested bacteria were previously identified by molecular method (PCR). All bacterial strains were maintained as lyophils at $-20^{\circ} \mathrm{C}$ in the collection present at SAFE and sub-cultured on King B media (KB) for $48 \mathrm{~h}$ at $25^{\circ} \mathrm{C}$.

\subsubsection{Antibacterial Activity Test}

The antibacterial activity was assessed following the method reported by Elshafie et al. [42]. A suspension of each tested bacteria was prepared at $10^{8} \mathrm{CFU} \mathrm{mL} \mathrm{m}^{-1}$ from fresh culture $(24 \mathrm{~h})$ adjusted by spectrophotometer UNICAM-UV 500 (Cambridge, UK). A mixture of $3 \mathrm{~mL}$ soft agar $(0.7 \%)$ and $1 \mathrm{~mL}$ of bacterial suspension $10^{8} \mathrm{CFU} \mathrm{mL}^{-1}$ was prepared and poured into a KB plate $(10 \mathrm{~mL}) .10 \mu \mathrm{L}$ of 
each EO concentration at $12,6,3 \mathrm{mg} / \mathrm{mL}$ and tetracycline at $1600 \mu \mathrm{g} \mathrm{mL} \mathrm{m}^{-1}$ were applied over blank $\operatorname{discs}(6 \mathrm{~mm}, \mathrm{OXOID})$.

The antibacterial activity was evaluated by measuring the diameter of the inhibition zone $(\mathrm{mm})$ around each treatment compared to tetracycline (positive control). The bacterial inhibition percentage (BIP) was calculated following the equation proposed by Elshafie et al. [43].

$$
\operatorname{BIP}(\%)=100-[(G C-G T) / G C \times 100],
$$

where: BIP represents the bacterial inhibition percentage, GC the average diameter of bacterial grown in control plate in $\mathrm{mm}$ and GT the average diameter of inhibition zone in $\mathrm{mm}$.

\subsection{Fungal Spore Germination Assay}

The inhibition of fungal spore germination of the most inhibited fungi resulting from the previous assay was determined using the liquid dilution method with three different concentrations of EO $(15,22$ and $45 \mu \mathrm{g} / \mu \mathrm{L})$. An aliquot of the three solutions was applied in contact with the tested fungi $\left(10^{8}\right.$ spores $/ \mathrm{mL}$ ) for $6 \mathrm{~h}$ at $28{ }^{\circ} \mathrm{C}$ and $80 \%$ relative humidity. Only PDB has been used as negative control $(-v e)$. Fifty $\mu \mathrm{L}$ of suspension containing spores and of solutions containing different $\mathrm{EO}$ concentration were dropped onto a Thoma cell counting chamber and the percentage spore germination was recorded after $36 \mathrm{~h}$ using a light microscope compared to negative control.

\subsection{Determination of MIC (96-Well Microplate Method)}

The minimum inhibitory concentration (MIC) was carried out against the most inhibited pathogenic fungi using a 96-well microplate (Nunc MaxiSorp ${ }^{\circledR}$, Vedbaek, Denmark) by a micro-dilution method following the method of Elshafie et al. [44]. Four milliliters of a liquid suspension from fresh fungal cultures $\left(96 \mathrm{~h}\right.$ ) was prepared at $10^{8}$ spore $/ \mathrm{mL}$ using Turbidimetry at optical density, OD $\approx 0.2 \mathrm{~nm}$. The EOs were prepared in potato dextrose broth (PDB) at 1500, 1700, 1800, 2000 and 2400 ppm for O. majorana EO and 500, 400, 300, 200 and 100 ppm for O. heracleoticum EO. The incorporation has been carried out using the mixture between PDB, Tween $20(0.2 \%)$ and the above-mentioned concentrations of tested EOs. The above-mentioned concentrations were proposed considering the results obtained from the initial antifungal screening assay. Two hundred microliters of each prepared concentration and $100 \mu \mathrm{L}$ of the prepared fungal suspension were added in each well; then the microplate was incubated at $24 \pm 2{ }^{\circ} \mathrm{C}$ and the absorbance was read at $\lambda=450 \mathrm{~nm}$ using the ELISA microplate reader instrument (DAS s.r.l., Rome, Italy) after 24, 48 , and $72 \mathrm{~h}$. The experiment was replicated in triplicate.

\subsection{Phytotoxic Activity}

The phytotoxic activity was evaluated considering the effect on germination and radical elongation of four species: Raphanus sativus, Lactuca sativa, Lepidium sativum and Solanum lycopersicum. These seeds are usually used in phytotoxicity assays for their easy germinability. All tested seeds were purchased from Blumen group srl (Emilia Romagna, Italy). The seeds were surface-sterilized in $95 \%$ ethanol for $15 \mathrm{~s}$ and sown in Petri dishes $(\varnothing=90 \mathrm{~mm})$, containing three layers of Whatman filter paper, impregnated with distilled water $(7 \mathrm{~mL}$, control) or the tested solution of the EO $(7 \mathrm{~mL})$, at the different doses. The germination assay was carried out at $20 \pm 1{ }^{\circ} \mathrm{C}$, with natural photoperiod. The EOs, in water-acetone mixture (99.5:0.5), were assayed at the doses of 100, 10, 1 and $0.1 \mu \mathrm{g} / \mathrm{mL}$. Controls performed with the water-acetone mixture alone showed no appreciable differences in comparison to controls in water alone. Seed germination was observed directly in Petri dishes every $24 \mathrm{~h}$. A seed was considered germinated when the protrusion of the radicle became evident [45]. After $120 \mathrm{~h}$ (on the fifth day), the effects on radicle elongation were measured in $\mathrm{cm}$. Each determination was repeated three times, using Petri dishes containing 10 seeds each. Data are expressed as the mean \pm SD for both germination and radicle elongation. 


\subsection{Statistical Analysis}

Results of the antimicrobial activity were statistically analyzed using the Statistical Package for the Social Sciences (SPSS) (version 13.0, Prentice Hall: Chicago, IL, USA, 2004) and applying one way ANOVA and Tukey post hoc test for detecting any significant differences between the different concentrations of tested EOs at $p<0.05$. Instead, data of each experiment for determination of phytotoxicity were statistically analyzed using the GraphPad Prism 6.0 software (GraphPad Software Inc., San Diego, CA, USA), followed by comparison of means (one-way ANOVA) using Dunnett's multiple comparisons test, at the significance level of $p<0.05$.

\section{Conclusions}

Our results showed that the two EOs could be utilized to control plant infections of all the tested fungi and Gram-positive and Gram-negative bacteria. Moreover, they are can inhibit the germination and the radical elongation of the tested species to different extents. The possible application of EOs in these fields is very promising because they are compatible with both environmental and human health. However, further investigations will need to study the antifungal and antibacterial efficacy of the single components of $O$. heracleoticum and O. majorana essential oil, and to evaluate their possible phytotoxic effects on crop species to confirm their possible use on a large scale as pesticides and/or herbicides.

Author Contributions: Conceptualization and writing-review and editing, V.D.F. and I.C.; methodology and investigation, T.D.P., L.C., M.R.S. and H.S.E.; data curation, F.N.; writing—original draft preparation, H.S.E., R.C., I.C. and F.N.

Funding: This research received no external funding.

Conflicts of Interest: The authors declare no conflict of interest.

\section{References}

1. Lopez-Reyes, J.G.; Spadaro, D.; Gullino, M.L.; Garibaldi, A. Efficacy of plant essential oils on postharvest control of rot caused by fungi on four cultivars of apples in vivo. Flavour Fragr. J. 2010, 25, 171-177. [CrossRef]

2. Nazzaro, F.; Fratianni, F.; De Martino, L.; Coppola, R.; De Feo, V. Effect of essential oils on pathogenic bacteria. Pharmaceuticals 2013, 6, 1451-1474. [CrossRef] [PubMed]

3. Rolim De Almeida, L.F.R.; Frei, F.; Mancini, E.; De Martino, L.; De Feo, V. Phytotoxic Activities of Mediterranean Essential Oils. Molecules 2010, 15, 4309-4323. [CrossRef] [PubMed]

4. Ramezani, S.; Saharkhiz, M.J.; Ramezani, F.; Fotokian, M.H. Use of essential oils as bioherbicides. J. Essent. Oil Bear. Plants 2008, 11, 319-327. [CrossRef]

5. Koul, O.; Walia, S.; Dhaliwal, G.S. Essential oils as green pesticides: Potential and constraints. Biopestic. Int. 2008, 4, 63-84.

6. Mancini, E.; Camele, I.; Elshafie, H.S.; De Martino, L.; Pellegrino, C.; Grulova, D.; De Feo, V. Chemical Composition and Biological Activity of the Essential Oil of Origanum vulgare ssp. hirtum from Different Areas in the Southern Apennines. Chem. Biodivers. 2014, 11, 639-651. [CrossRef]

7. Jerković, I.; Mastelić, J.; Miloš, M. The impact of both the season of collection and drying on the volatile constituents of Origanum vulgare L. ssp. hirtum grown wild in Croatia. Int. J. Food Sci. Technol. 2001, 36, 649-654. [CrossRef]

8. Tripathy, B.; Satyanarayana, S.; Abedulla Khan, K.; Raja, K. An Updated Review on Traditional Uses, Taxonomy, Phytochemistry, Pharmacology and Toxicology of Origanum majorana. Int. J. Pharma Res. Health Sci. 2017, 5, 1717-1723.

9. Dzamic, A.; Sokovic, M.; Ristic, M.S.; Grujic-Jovanovic, S.; Vukojevic, J.; Marin, P.D. Chemical composition and antifungal activity of Origanum heracleoticum essential oil. Chem. Nat. Compd. 2008, 44, 659-660. [CrossRef]

10. Kokkini, S.; Karousou, R.; Hanlidou, E.; Lanaras, T. Essential oil composition of Greek (Origanum vulgare ssp. hirtum) and Turkish (O. onites) Origanum: A tool for their distinction. J. Essent. Oil Res. 2004, 16, 334-338. [CrossRef] 
11. Mith, H.; Clinquart, A.; Zhiri, A.; Daube, G.; Delcenserie, V. The impact of Origanum (Origanum heracleoticum) essential oil and carvacrol on virulence gene transcription by Escherichia coli O157:H7. FEMS Microbiol. Lett. 2015, 362, 1-7. [CrossRef]

12. Abbassy, M.A.; Abdelgaleil, S.A.; Rabie, R.Y. Insecticidal and synergistic effects of Origanum majorana essential oil and some of its major constituents. Entomol. Exp. Appl. 2009, 131, 225-232. [CrossRef]

13. Brosche, T.; Vostrowsky, O.; Gemeinhardt, F.; Asmus, U.; Knobloch, K. On the Essential Oil Components from Majorana hortensis Moench. Z. Naturforsch. C 1981, 36, 23-29. [CrossRef]

14. Kadoglidou, K.; Lagopodi, A.; Karamanoli, K.; Vokou, D.; Bardas, G.A.; Menexes, G.; Constantinidou, H.I.A. Inhibitory and stimulatory effects of essential oils and individual monoterpenoids on growth and sporulation of four soil-borne fungal isolates of Aspergillus terreus, Fusarium oxysporum, Penicillium expansum, and Verticillium dahliae. Eur. J. Plant Pathol. 2011, 130, 297-309. [CrossRef]

15. Daferera, D.J.; Ziogas, B.N.; Polissiou, M.G. The effectiveness of plant essential oils on the growth of Botrytis cinerea, Fusarium sp. and Clavibacter michiganensis subsp. michiganensis. Crop Prot. 2003, 22, 39-44. [CrossRef]

16. Stavropoulou, A.; Loulakakis, K.; Magan, N.; Tzortzakis, N. Origanum dictamnus oil vapour suppresses the development of grey mould in eggplant fruit in vitro. BioMed Res. Int. 2014, 2014, 562679. [CrossRef] [PubMed]

17. Felsociova, S.; Kacaniova, M.; Horská, E.; Vukovic, N.; Hleba, L.; Petrová, J.; Hajduová, Z. Antifungal activity of essential oils against selected terverticillate penicillia. Ann. Agric. Environ. Med. 2015, 22, 38-42. [CrossRef]

18. Deleanu, M.; Popa, E.E.; Popa, M.E. Chemical Composition and Active Properties Evaluation of Wild Oregano (Origanum Vulgare) and Ginger (Zingiber Officinale-Roscoe) Essential Oils. Rev. Chim. 2018, 69, 1927-1933.

19. Bayramoglu, E.E.; Gulumser, G.; Karaboz, I. Ecological and innovative fungicide for the leather industry: Essential oil of Origanum minutiflorum. JALCA 2006, 101, 96-104.

20. Soylu, E.M.; Kurt, S.; Soylu, S. In vitro and in vivo antifungal activities of the essential oils of various plants against tomato grey mould disease agent Botrytis cinerea. Int. J. Food Microbiol. 2010, 143, 183-189. [CrossRef]

21. Veldhuizen, E.J.; Tjeerdsma-van Bokhoven, J.L.; Zweijtzer, C.; Burt, S.A.; Haagsman, H.P. Structural requirements for the antimicrobial activity of carvacrol. J. Agric. Food Chem. 2006, 54, 1874-1879. [CrossRef] [PubMed]

22. Elshafie, H.S.; Armentano, M.; Carmosino, M.; Bufo, S.; De Feo, V.; Camele, I. Cytotoxic activity of Origanum vulgare L. on hepatocellular carcinoma cell line HepG2 and evaluation of its biological activity. Molecules 2017, 22, 1435. [CrossRef] [PubMed]

23. Sarac, N.; Ugur, A. Antimicrobial activities of the essential oils of Origanum onites L., Origanum vulgare L. subspecies hirtum (Link) Ietswaart, Satureja thymbra L., and Thymus cilicicus Boiss. \& Bal. growing wild in Turkey. J. Med. Food 2008, 11, 568-573. [CrossRef] [PubMed]

24. Özcan, M.M.; Sadıç, O.; Özkan, G. Inhibitory effects of spice essential oils on the growth of Bacillus species. J. Med. Food 2006, 9, 418-421. [CrossRef] [PubMed]

25. Chudasama, K.S.; Thaker, V.S. Screening of potential antimicrobial compounds against Xanthomonas campestris from 100 essential oils of aromatic plants used in India: An ecofriendly approach. Arch. Phytopathol. Plant Protect. 2012, 45, 783-795. [CrossRef]

26. Araniti, F.; Landi, M.; Lupini, A.; Sunseri, F.; Guidi, L.; Abenavoli, M.R. Origanum vulgare essential oils inhibit glutamate and aspartate metabolism altering the photorespiratory pathway in Arabidopsis thaliana seedlings. J. Plant Physiol. 2018, 231, 297-309. [CrossRef]

27. Kordali, S.; Cakir, A.; Ozer, H.; Cakmakci, R.; Kesdek, M.; Mete, E. Antifungal, phytotoxic and insecticidal properties of essential oil isolated from Turkish Origanum acutidens and its three components, carvacrol, thymol and p-cymene. Bioresour. Technol. 2008, 99, 8788-8795. [CrossRef]

28. Vasilakoglou, I.; Dhima, K.; Paschalidis, K.; Ritzoulis, C. Herbicidal potential on Lolium rigidum of nineteen major essential oil components and their synergy. J. Essent. Oil Res. 2013, 25, 1-10. [CrossRef]

29. De Assis Alves, T.; Pinheiro, P.F.; Praça-Fontes, M.M.; Andrade-Vieira, L.F.; Corrêa, K.B.; de Assis Alves, T.; Soares, T.C.B. Toxicity of thymol, carvacrol and their respective phenoxyacetic acids in Lactuca sativa and Sorghum bicolor. Ind. Crops Prod. 2018, 114, 59-67. [CrossRef] 
30. Pinheiro, P.F.; Costa, A.V.; Alves, T.D.A.; Galter, I.N.; Pinheiro, C.A.; Pereira, A.F.; Fontes, M.M.P. Phytotoxicity and cytotoxicity of essential oil from leaves of Plectranthus amboinicus, carvacrol, and thymol in plant bioassays. J. Agric. Food Chem. 2015, 63, 8981-8990. [CrossRef]

31. Pignatti, S.; Guarino, R.; La Rosa, M. Flora d'Italia; Edagricole: Bologna, Italy, 2017. Available online: https://img.ibs.it/pdf/9788850652426.pdf (accessed on 20 June 2019).

32. Council of Europe. European Pharmacopeia, 5th ed.; Council of Europe: Strasbourg Cedex, France, 2014; Volume I, pp. 217-218.

33. Jennings, W.; Shibamoto, T. Qualitative Analysis of Flavour and Fragrance Volatiles by Glass Capillary Gas Chromatography; Academic Press: New York, NY, USA, 1980.

34. Davies, N.W. Gas chromatographic retention indices of monoterpenes and sesquiterpenes on methyl silicone and Carbowax 20M phases. J. Chromatogr. 1990, 503, 1-24. [CrossRef]

35. Adams, R.P. Identification of Essential Oil Components by Gas Chromatography/Mass Spectroscopy, 4th ed.; Allured Publishing: Carol Stream, IL, USA, 2007.

36. Goodner, K.L. Practical retention index models of OV-101, DB-1, DB-5, and DB-Wax for flavor and fragrance compounds. LWT Food Sci. Technol. 2008, 41, 951-958. [CrossRef]

37. McLafferty, F.W. The Wiley Registry of Mass Spectral Data, with NIST Spectral Data CD Rom, 7th ed.; John Wiley \& Sons: New York, NY, USA, 1998.

38. White, T.J.; Bruns, T.; Lee, S.; Taylor, J.W. Amplification and direct sequencing of fungal ribosomal RNA genes for phylogenetics. In PCR Protocols: A Guide to Methods and Applications; Innis, M.A., Gelfand, D.H., Sninsky, J.J., White, T.J., Eds.; Academic Press: New York, NY, USA, 1990; pp. 315-322.

39. Altschul, S.F.; Madden, T.L.; Schaffer, A.A.; Zhang, J.; Zhang, Z.; Miller, W.; Lipman, D.J. Gapped BLAST and PSIBLAST: A new generation of protein database search programs. Nucleic Acids Res. 1997, 25, 3389-3402. [CrossRef] [PubMed]

40. Elshafie, H.S.; Ghanney, N.; Mang, S.M.; Ferchichi, A.; Camele, I. An in vitro attempt for controlling severe phyto and human pathogens using essential oils from Mediterranean plants of genus Schinus. J. Med. Food 2016, 19, 166-173. [CrossRef] [PubMed]

41. Zygadlo, J.A.; Guzman, C.A.; Grosso, N.R. Antifungal properties of the leaf oils of Tagetes minuta L. and Tagetes filifolia Lag. J. Essent. Oil Res. 1994, 6, 617-621. [CrossRef]

42. Elshafie, H.S.; Sakr, S.; Mang, S.M.; De Feo, V.; Camele, I. Antimicrobial activity and chemical composition of three essential oils extracted from Mediterranean aromatic plants. J. Med. Food 2016, 19, 1096-1103. [CrossRef]

43. Elshafie, H.S.; Racioppi, R.; Bufo, S.A.; Camele, I. In vitro study of biological activity of four strains of Burkholderia gladioli pv. agaricicola and identification of their bioactive metabolites using GC-MS. Saudi J. Biol. Sci. 2017, 24, 295-301. [CrossRef]

44. Elshafie, H.S.; Mancini, E.; De Martino, L.; Pellegrino, C.; Camele, I.; De Feo, V. Antifungal activity of some constituents of Origanum vulgare L. essential oil against postharvest disease of peach fruit. J. Med. Food 2015, 18, 929-934. [CrossRef]

45. Bewley, J.D. Seed germination and dormancy. Plant Cell 1997, 9, 1055. [CrossRef]

Sample Availability: Samples of the O. heracleoticum and O. majorana essential oils are available from the authors. 